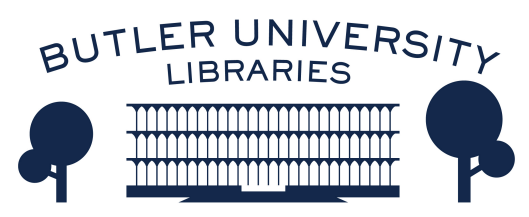

Journal of Hindu-Christian Studies

Volume 9

Article 5

January 1996

\title{
Scripture as a Source of Knowledge in Hinduism
}

Anantanand Rambachan

Follow this and additional works at: https://digitalcommons.butler.edu/jhcs

Part of the Religion Commons

\section{Recommended Citation}

Rambachan, Anantanand (1996) "Scripture as a Source of Knowledge in Hinduism," Journal of HinduChristian Studies: Vol. 9, Article 5.

Available at: https://doi.org/10.7825/2164-6279.1127

The Journal of Hindu-Christian Studies is a publication of the Society for Hindu-Christian Studies. The digital version is made available by Digital Commons @ Butler University. For questions about the Journal or the Society, please contact cbauman@butler.edu. For more information about Digital Commons @ Butler University, please contact digitalscholarship@butler.edu. 


\title{
Scripture as a Source of Knowledge in Hinduism
}

\author{
Anantanand Rambachan \\ St Olaf College
}

\begin{abstract}
Most of us hear the word "scripture" without stumbling over it. Using it, we give the impression, even to ourselves, that there is understanding of what the term means; that we all know what scripture is. On reflection, it turns out that this is hardly the case. ${ }^{1}$
\end{abstract}

ONE OF WILFRED Cantwell Smith's principal concerns in What is Scripture? is to highlight the variety of texts which are construed as scripture and the variety of attitudes which human history reveals towards such texts. We may begin by noting, for example, the inappropriateness of the term "scripture" (from scribere - to write) for the Vedas because of its emphasis on the written word as opposed to the word which is heard and preserved through oral transmission. The Vedas are more aptly referred to in Sanskrit as śruti (that which is heard) or sabda (sound), and these terms correctly underline the traditionally aural character of these texts. ${ }^{2}$ The Hindu tradition, especially in the Vedānta schools, has relied on and elaborated the idea of śruti as a pramāna (source of valid knowledge) and any unique features of this idea must be included in the "richness and depth with which human life has been imbued over long stretches of time for most human beings and societies, through their use of, their involvement with their scripture". ${ }^{3}$

As indicated above, the doctrine of the śruti as a source of valid knowledge received particular attention in the Vedānta schools and my discussion of this doctrine is confined largely to its formulation in the Advaita (non-dual) tradition of Sankara. I will, however, make some comparative references to Rāmānuja and the Viśistāâdvaita tradition where appropriate. While these theological giants of the Hindu tradition differ radically in their interpretation of the Vedas, they do share certain common assumptions about the nature of scripture as a source of valid knowledge.

While there are important differences in the way in which the authority of sruti is conceived, the orthodox schools of Indian philosophy include it among the sources of valid knowledge and refer to it as sabdapramāna. ${ }^{4}$ The term pramā indicates valid cognitions and the special source of such a cognition is termed a pramāna. A pramāna, therefore, may be thought of as a source or cause of valid knowledge. In the words of Śankara, "a means of knowledge is or is not such according as it leads or does not lead to valid knowledge. Otherwise even a post, for instance, would be considered a means of knowledge in perceiving sound, etc." 5

One of the very important consequences of understanding and listing the sruti, along with perception and inference, etc., as a source of valid knowledge is that the śruti must satisfy, as far as possible, the criteria of being a pramāna. Scripture cannot claim a special status which exempts it from being subject to the same standards as other sources. In the Advaita school, novelty and non-contradictedness are considered to be the essential characteristics of valid knowledge. ${ }^{6}$ Most of the emphasis, traditionally, has been placed on noncontradictedness as the essential test of truth. An invalid statement or erroneous experience can be negated on the basis of being contradicted: 
The view of scripture in the Hindu tradition as a source of valid knowledge and the necessity to meet the standards of such knowledge require, it seems to me, that the defenders of the śruti recognize a continuous obligation to articulate, clarify, and defend its claims in dialogue with world views which either challenge or affirm its claims. An advocate of a śruti viewpoint cannot be indifferent to rival claims which are derived from the empirical sciences or other revelatory sources. A belief in the principle of non-contradictedness should engender an optimistic faith which is enthusiastic for dialogue with other insights about the ultimate nature of reality. Sruti-based positions provide an excellent perspective from which the Hindu tradition could vigorously engage both secular and sacred traditions in conversation. It is unfortunate, for reasons which I have tried to explore elsewhere, that a lack of interest in the sruti has also resulted in a loss of intellectual vigour in Hinduism and in a lukewarm desire for dialogue. ${ }^{7}$ One of the common claims of the contemporary Hindu apologetic, for example, is that its world view is "scientific", but we are yet to see, from within the Hindu tradition, a serious explication of its viewpoint in relation to the conclusions of the empirical pramanna. ${ }^{8}$

While admitting scripture as a source of valid knowledge, the Vedānta traditions also define the specific knowledge for which the sruti may be regarded as authoritative. The justification for a special means of knowledge, like scripture, is that it provides knowledge of those things which cannot be known through any of the other available sources of knowledge. For the Advaita tradition, the two subjects which are inaccessible to all other pramannas and known exclusively through the Vedas are dharma and brahman. ${ }^{9}$ For Śankara, the nature of dharma, which includes appropriate ethical as well as ritual action, is known only from the Vedas.

The knowledge of one action being right and another wrong is based on scripture only; for it lies out of the recognizance of the senses, and there moreover is, in the case of right and wrong, an entire want of binding rules as to place, time and occasion. What in one place, at one time, on one occasion is performed as a right action, is a wrong action in another place, at another time, on another occasion; none therefore can know, without scripture, what is either right or wrong. ${ }^{10}$

The śruti, as we noted above, also serves as a valid source for our knowledge of brahman (the limitless) and it is in relation to the revelation of brahman that the Vedānta traditions articulate the most detailed rationale for the nature and necessity of the scripture as a pramanna. The cornerstone of Śankara's argument for scripture as a valid means of knowledge for brahman is that given the nature of brahman as nirguna (free from all qualities), a pramanna which consists of words is the only logical means. Sound, sensation, form, taste, and scent are the respective spheres of the sense organs. Since brahman, however, has no sound, touch, form, taste, or smell, it is outside the domain of the sense organs. Moreover, argues Śankara, perceptual knowledge requires a process of objectifying the thing to be known, and brahman, being the eternal subject of all experiences, cannot be objectified. Although Rāmānuja differs from Sankara in his understanding of the nature of brahman, it is significant to note that he refutes, in no uncertain terms, the possibility of knowing brahman through perception. $^{11}$

Since perception is an inappropriate means of knowledge for brahman, the view of both Śarikara and Rāmānuja is that inference, which is more or less dependent on perception for its data, will not be helpful. Rāmānuja sums up the basic Vedānta viewpoint.

Thus the inference of a creative Lord which claims to be in agreement with observation is refuted by reasoning which is itself in agreement with observation, and we hence conclude that 
Scripture is the only source of knowledge with regard to a supreme soul that is the Lord of all and constitutes the highest Brahman. What Scripture tells us of is a being which comprehends within itself infinite, altogether unsurpassable excellences such as omnipotence and so on, is antagonistic to all evil, and totally different in character from whatever is cognised by other means of knowledge. ${ }^{12}$

Sruti fulfils the criteria of being a valid source of knowledge by generating a fruitful knowledge which cannot be obtained through another source and which is uncontradicted.

Is or is not certain and fruitful knowledge generated by passages setting forth the nature of the Self, and if so, how can they lose their authority? Do you not see the result of knowledge in the removal of all the evils which are the root of transmigration, such as ignorance, grief, delusion and fear? ${ }^{13}$

Since Śankkara's arguments for scripture as a source of valid knowledge are mainly epistemological (i.e. that scripture fulfils the criteria of being a pramäna), it is important to underline the point that the Advaita tradition does not try to establish the validity of the texts by reference to God's omniscience. The reason is that since the tradition finds it impossible to establish the existence and nature of God through inferential reasoning, one ends up with a hopelessly circular argument, "the omniscience of the Lord being established on the doctrine of Scripture, and the authority of Scripture again being established on the omniscience of the Lord". 14

The admission of scripture as a source of valid knowledge in the Hindu tradition does not imply the redundancy of reason. While Śankara and Rāmānuja reject the argument that the nature of brahman may be ascertained through inferential reasoning independent of scripture, they are both supportive of the use of argument which is in harmony with revelation. Inferential reasoning independent of sruti is inconclusive since brahman possesses no perceptible characteristics. Sāmānyatodrstanumāna, however, which corresponds in modern logic to analogical reasoning, is widely employed by Vedānta commentators. This type of reasoning is not viewed as a pramāna, but operates as an ancillary to a pramäna. Its function is to bolster the source of knowledge. Reason has to be used in ascertaining and clarifying the meaning of scripture in debates with schools that accept the authority of the sruti but offer different interpretations. It also has a wider role in defending scripture against rival schools which reject both its authority as a source of knowledge and its viewpoint. Rāmānuja again sums up the Vedānta position.
A theory which rests exclusively on arguments derived from human reason may, at some time or place, be disestablished by arguments devised by people more skilful than you in reasoning; and thus there is no getting over the objection founded on the invalidity of all mere argumentation. The conclusion from all this is that with regard to supersensuous matters, Scripture alone is authoritative, and reasoning is to be applied only to the support of Scripture. ${ }^{15}$

How does the proponent of the sruti respond when there is conflict between human experience and scripture? If the issue cannot be resolved by mutually acceptable forms of argument, the proponent will proffer the uniqueness of scripture as a means of knowledge. In the Vedānta-Sütras, for example, the question of brahman creating the world without any organs of action is raised since one does not see beings without bodily organs creating anything. While noting that one should be cautious about generalizations from experience, Śnikara falls back upon the authority of pramāna.

The transcendent highest Brahman can 
be fathomed by means of Scripture only, not by mere reasoning. Nor are we obliged to assume that the capacity of one being is exactly like that which is observed in another. 16

One of the important features of the Vedānta characterization of scripture as a pramāna which may also open fruitful areas for dialogue with the Christian tradition is the concern to circumscribe the scripture's sphere of authority. Commentators, like Sankara, identify the subject matter for which scripture is a source of valid knowledge, but also the topics for which it does not speak authoritatively. In this sense, the sruti is like all other pramannas in having a limited revelatory role.

Scripture, as noted above, is intended for the revelation of dharma and brahman, both of which cannot be known through another source. Its purpose is not to disclose matters within the range of human experience, ascertainable through any of the other pramānas, like perception or inference. If a scriptural statement, therefore, contradicts an established fact of everyday human experience, the former cannot be considered authoritative since such a matter would be outside its sphere of authority. Sankara is clear on this point.

Sruti is an authority only in matters not perceived by means of ordinary instruments of knowledge such as pratyaksha or immediate perception;i.e., it is an authority as to the mutual relation of things as means to ends, but not in matters lying within the range of pratyaksha; indeed, sruti is intended as an authority only for knowing what lies beyond the range of human knowledge ... A hundred śrutis may declare that fire is cold or that it is dark; still they possess no authority in the matter. ${ }^{17}$

If śruti did describe fire as being cold or dark, we would be obliged to construe its meaning figuratively since the purpose of scripture is not to create anything anew or to reverse the nature of anything. The texts are fundamentally revelatory in purpose and are concerned with expressing things as they are.

Things in the world are known to possess certain fixed characteristics such as grossness or fineness. By citing them as examples the scripture seeks to tell us about some other thing which does not contradict them. They would not cite an example from life if they wanted to convey an idea of something contradictory to it. Even if they did, it would be to no purpose, for the example would be different from the thing to be explained. You cannot prove that fire is cold, or that the sun does not give heat, even by citing a hundred examples, for the facts would already be known to be otherwise through another means of knowledge. And one means of knowledge does not contradict another, for it only tells us about those things that cannot be known by another means. Nor can scripture speak about an unknown thing without having recourse to conventional words and their meanings. ${ }^{18}$

The Advaita tradition is very specific about some of the topics which are not authoritatively revealed in the scripture. It is not the purpose of scripture, for example, to inform us of the details and order of the creation of the world since we neither observe nor are told by the texts that the welfare of human beings depends on this kind of knowledge. Such descriptions, argues Śankara, really have as their aim the revelation of the nature of the absolute. ${ }^{19}$ It is also not the concern of scripture to describe the nature of the human being with regard to those characteristics which are available for observation. "The Lord, on the other hand, about whom ordinary experience tells us nothing, is to be considered as the special topic of all scriptural passages. 20

The case for scripture as a means of knowledge in the Hindu tradition is based on the belief that there are realities (or a reality) whose true nature cannot be ascertained by other ways of knowing. Such a premise, it appears to me, is intellectually 
defensible, especially when scripture is willing to subject its claims to assessment by other sources of knowledge and to question the conclusions of these sources.

The argument that each pramāna has a unique sphere of authority may appear to be one which inhibits dialogue among other religious traditions and between religion and the empirical sciences. It would seem to me, however, that the common interest which religions and the empirical sciences have in the nature of reality make them natural dialogue partners. If a religion understands the authoritative sources of other religious traditions as rival pramanas, there is an obvious epistemological necessity for dialogue to understand and explain their similar or dissimilar points of view. A similar case may be made for dialogue with the empirical sciences when the propositions of the latter converge with or stand opposed to religious claims. The assumption that valid sources of knowledge cannot contradict each other suggests that human inquiry, in. the widest sense, will some day converge, but in the meantime, the pramanna approach urges us to account for our differences and similarities. The view of scripture as a pramāna, provides a sound basis for dialogue and holds out the possibility that all who are engaged in the quest for knowledge, in whatever discipline, may be enriched by each other.

\section{Notes}

1. W.C. Smith, What is Scripture?, Minneapolis: Fortress Press, 1993, p.1.

2. A student of the Vedas is referred to, traditionally, as srotriya (one who hears).

3. W.C. Smith, What is Scripture?, p.16. While Smith argues for attentiveness to diversity in the materials which are regarded as scripture and in their interpretation throughout history, there is no discussion in his work about the significant Hindu notion of the śruti as pramāna. The latter term does not occur in his discussion of the Hindu tradition.

4. In this article I use the worlds śruti and sabda to refer to the Vedas. It must be recognized, however, that the term sruti as revelation is not limited to the Vedic texts.

5. The Brhadäranyaka Upanisad: with the commentary of Sarikarācarrya, Swami Madhavananda (transl.), Calcutta: Advaita Ashrama, 1975, II.1.20, p.214. Hereafter abbreviated BR.U.B.

6. See e.g. The Vedānta Paribhāsā of Dharmaräja Adhvarindra, Swami Madhavananda (transl.), Belur Math, Howrah: The Ramakrishna Mission Saradapitha, 1972, Ch.1; p.5.

7. See Anantanand Rambachan, The Limits of Scripture: Vivekananda's Reinterpretation of the Authority of the Vedas, Honolulu: University of Hawaii Press, 1994.

8. This is also lamentable because of the significant number of people from the Indian subcontinent who work in the fields of scientific and technological research.

9. See, e.g., The Vedanta Sütras: with the commentary of Sañkarâcārya, George Thibaut (transl.), Sacred Books of the East Series, Vol. 34, Delhi: Motilal Banarsidass, 1988, II.I.6. Hereafter abbreviated VSS.

10. VSS, Vol.38, III.I.25. The existence of the self in future lives and the appropriate means for attaining happiness and avoiding unhappiness in those lives fall within the sphere of dharma and are known only from the Vedas.

11. The Vedanta-Sutras: with the commentary of Rāmānuja, George Thibaut (transl.), Sacred Books of the East Series, Vol. 48, Delhi: Motilal Banarsidass, 1990, I.I.3. Hereafter abbreviated VSR. While both Sarikara and Rāmannuja see the words of Vedas as the authoritative source for the knowledge of the absolute, there is considerable discussion on the problem of language relation to brahman and the special ways in which words are used in communicating valid knowledge of the limitless. This subject exceeds the scope of this article and the reader may want to consult Anantanand Rambachan, Accomplishing the Accomplished: The Vedas as a Source of Valid Knowledge in Śankara, Honolulu: University of Hawaii Press, 1991. See, in particular, Ch.3.

12. Ibid.

13. BR.U.B. I.iv.7.

14. VSS II.2.38. 
15. VSR II.I.12.

16. VSS II.I.31. On the same sütra Rāmānuja comments as follows: "That for which the sacred word is the only means of knowledge, and which is different from all other things, is capable of producing those effects also of the instrumental means of which it is destitute". See also their respective commentaries on sütra II.I.27.
17. A. Mahadeva Sastry (transl.), The Bhagavadgita: : with the commentary of Śankarācārya, Madras: Samata Books, 1977, 18:66.

18. BR.U.B. II.I.20. It is obvious that in the view of Sarikara, the revelations of scripture are not opposed to fact.

19. See VSS I.4.14.

20. Ibid., I.3.7. 